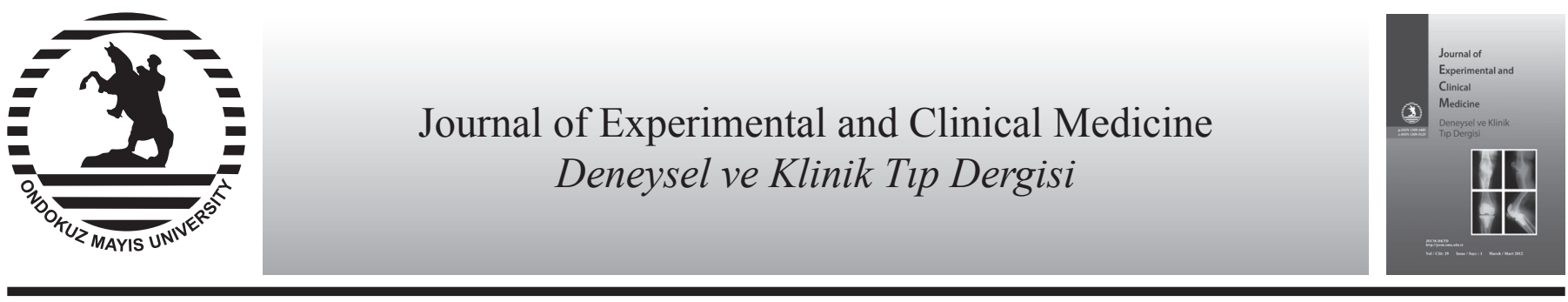

Clinical Research

doi: $10.5835 /$ jecm.omu.29.01.002

\title{
The factors affecting women's contraceptive choices
}

\author{
Emel Kurtoglu*, Haldun Arpaci \\ Eregli State Hospital, Obstetric and Gynaecology Department, Konya, Turkey
}

\begin{tabular}{|c|c|}
\hline ARTICLE INFO & ABSTRACT \\
\hline $\begin{array}{ll}\text { Article History } \\
\text { Received } & 17 / 11 / 2011 \\
\text { Accepted } & 29 / 11 / 2011\end{array}$ & $\begin{array}{l}\text { The purpose of this study is to investigate the factors affecting women's contraceptive } \\
\text { choices. In this study, we included } 507 \text { subjects, of whom } 108 \text { were nulliparous and } 399 \\
\text { of whom were multiparous. All were married between } 15-49 \text { years old and had applied } \\
\text { to the Ministry of Health Konya Eregli Hospital Obstetric and Gynaecology Polyclinic. }\end{array}$ \\
\hline $\begin{array}{l}\text { * Correspondence to } \\
\text { Emel Kurtoglu } \\
\text { Eregli State Hospital, } \\
\text { Obstetric and Gynaecology } \\
\text { Department, Eregli, } \\
\text { Konya, Turkey } \\
\text { e- mail: emel0022@mynet.com }\end{array}$ & $\begin{array}{l}\text { traceptive choices, the factors affecting them, the reasons for leaving previous methods } \\
\text { they had used, working and educational status and their knowledge about the contra- } \\
\text { ceptive methods. The mean age of the study group was } 33.6 \pm 7 \text {. While } 85.21 \%(\mathrm{n}=432) \\
\text { were using modern methods, } 14.79 \%(\mathrm{n}=75) \text { were using traditional methods. When the } \\
\text { contraceptive methods being used were examined, it was detected that the condom was } \\
\text { the most used method with } 30.18 \%(\mathrm{n}=153) \text { and the use of once-in-three months proges- } \\
\text { terone }(\mathrm{n}=2) \text {, levonorgestrel-releasing intrauterine devices }(\mathrm{n}=2) \text { and lactation }(\mathrm{n}=2) \text { had } \\
\text { the lowest percentages }(0.40 \%) \text {. Among the study group, } 65.50 \% \text { of the women were } \\
\text { influenced by their husbands about the choice of contraceptive, } 52.27 \% \text { were counselled }\end{array}$ \\
\hline $\begin{array}{l}\text { Keywords: } \\
\text { Contraceptive method } \\
\text { Choice } \\
\text { Physician counselling } \\
\text { Conscious }\end{array}$ & $\begin{array}{l}\text { reason for leaving the previous contraception method was losing confidence and becom- } \\
\text { ing pregnant. In the study group, only } 48.32 \% \text { of the women had knowledge about their } \\
\text { contraceptive methods. It was thought that the women were affected by their husbands } \\
\text { and their neighbours in their choice of contraception and they were almost unconsciously } \\
\text { using their chosen methods. Counselling by physicians to make women more conscious } \\
\text { of their choice and choose the most appropriate contraceptive method is recommended. } \\
\text { J. Exp. Clin. Med., 2012; } 29: 6-8\end{array}$ \\
\hline
\end{tabular}

(C) 2012 OMU All rights reserved

\section{Introduction}

In many populations, women are expected to find a solution for contraception, so they have anxiety about becoming pregnant from puberty to the post-menopause period (Stubblefield et al., 2007). The choice of contraception is one of the most important decisions to be made by couples and many factors may affect this, such as the couples' concordance, religion, socioeconomic condition, knowledge and physician counselling (Grewal and Burkman, 2003).

Contraceptive methods can be classified into hormonal and non-hormonal methods. Hormonal methods include oestrogen and progesterone combinations, progesterone on its own containing preparations and levonorgestrel-releasing intrauterine devices (Stubblefield et al., 2007). Non-hormonal methods consist of barrier methods such as condoms, intrauterine devices and traditional methods like lactation and coitus interruptus (Stubblefield et al., 2007). Sterilisation, as its contraception effect is too high, seems to be more popular today especially among middle-aged couples as the induced abortion is another method used to terminate pregnancies by medical and surgical means, but it carries high risks of morbidity and mortality for women.

In previous studies of contraception methods and the factors affecting women's choices there were different results according to the region where the women lived, the working conditions, educational status and age groups (Alpu and Fidan, 2006; Topsevar et al., 2006; Mosher and Jones, 2010).

The purpose of this study was to investigate how these women choose their contraceptive methods and the factors affecting this choice.

\section{Materials and methods}

We included 507, 15 to 49 year-old women, 108 of them were nulliparous and 399 of them were multiparous, who had attended Konya Eregli State Hospital Gynaecology and Obstetric policlinic and were using contraception methods. Questions were asked and recorded by filling an inquiry form during face-to-face conversations about the women's contraceptive methods, the effect of their husbands', neighbourhoods', physicians' views or other possible factors on 
contraceptive choice, their knowledge about contraceptive methods used, their reasons for leaving a previous contraception method, systemic diseases (hypertension, diabetes mellitus, vascular disease, epilepsy and asthma etc.), drug usage, educational status and working conditions.

The analysis of data was done using the SPSS for Windows 11.5 program. Descriptive statistics were indicated as average \pm standard deviation for continuous variables. Categorical variables were expressed as case number and percentage. Categorical variables were examined by Pearson's chi-square test and $\mathrm{p}<0.05$ was accepted as statistically significant.

\section{Results}

The study group included 507 women and the mean age was 33.6 \pm 7.0 . The demographic characteristics of the women are shown in Table 1.

\begin{tabular}{ll}
\multicolumn{2}{l}{ Table 1. Demographic characteristics of the women } \\
\hline Age & $\mathbf{n}=\mathbf{5 0 7}$ \\
Nulliparous & $33.6 \pm 7.0$ \\
Multiparous & $108(21 \%)$ \\
Employee & $399(78 \%)$ \\
Housewife & $95(18 \%)$ \\
Primary and secondary education & $412(81 \%)$ \\
Higher education & $455(89 \%)$ \\
Systemic diseases* & $52(10 \%)$ \\
\hline
\end{tabular}

*Asthma, coronary artery diseases, depression, Cooley's anaemia carrier, vertigo, rheumatoid arthritis

While 432 women were using modern contraceptive methods $(85.01 \%), 75$ women were using traditional methods $(14.79 \%)$. In all groups, the most chosen method was the male condom $(30.18 \%, n=153)$, however the least used methods were once-in-three months injectable progesterone $(0.40 \%, \mathrm{n}=2)$, levonorgestrel-releasing intrauterine device (IUDs) $(0.40 \%, \mathrm{n}=2)$ and lactation $(0.40 \%, \mathrm{n}=2)$. The contraceptive methods used by all groups are shown in Table 2.

\section{Table 2. Contraceptive methods of the women}

\begin{tabular}{ll} 
& $\mathbf{n = 5 0 7}$ \\
\hline Modern methods: & $\mathbf{4 3 2}(\mathbf{8 5 \% )}$ \\
Male condom & $153(30 \%)$ \\
Intrauterine device & $143(28 \%)$ \\
Oral contraceptives & $90(17 \%)$ \\
Once-a-month injectable combination & $5(0.98 \%)$ \\
Once-in-three months injectable & $2(0.40 \%)$ \\
progesterone & $2(0.40 \%)$ \\
Levonorgestrel-releasing IUDs & $37(7 \%)$ \\
Tubal ligation & $\mathbf{7 5}(\mathbf{1 4 \%})$ \\
Traditional methods: & $68(13 \%)$ \\
Coitus interruptus & $2(0.40 \%)$ \\
Lactation & $5(0.98 \%)$ \\
Natural family planning & \\
\hline
\end{tabular}

When the study group was separated into groups according to age, parity, working condition and education status, the use of modern and traditional contraceptive methods differed. Women who was 15-35 year-old and nulliparous had greater tendency to choose modern methods $(\mathrm{p}<0.001)$. There were no significantly difference in choosing modern contraception methods between employed women and housewives $(p=0.052)$. Also, education status did not significantly affect the choice of modern methods $(\mathrm{p}=0.128)$. The distribution is shown in Table 3.

Table 3. The contraceptive methods in different ages, parities,
working conditions and educational status

\begin{tabular}{|c|c|c|}
\hline Contraceptive methods & Modern methods & Traditional methods \\
\hline $\begin{array}{l}\text { Age } 15 \text { to } 35 \\
(\mathrm{n}=216)\end{array}$ & $\begin{array}{l}197 \\
(91 \%)\end{array}$ & $\begin{array}{l}19 \\
(8 \%)\end{array}$ \\
\hline $\begin{array}{l}\text { Age } 35 \text { to } 49 \\
(\mathrm{n}=291)\end{array}$ & $\begin{array}{l}235 \\
(80 \%)\end{array}$ & $\begin{array}{l}56 \\
(19 \%)\end{array}$ \\
\hline $\begin{array}{l}\text { Nulliparous } \\
(\mathrm{n}=108)\end{array}$ & $\begin{array}{l}102 \\
(94 \%)\end{array}$ & $\begin{array}{l}6 \\
(5 \%)\end{array}$ \\
\hline $\begin{array}{l}\text { Multiparous } \\
(\mathrm{n}=399)\end{array}$ & $\begin{array}{l}330 \\
(82 \%)\end{array}$ & $\begin{array}{l}69 \\
(17 \%)\end{array}$ \\
\hline $\begin{array}{l}\text { Employees } \\
(\mathrm{n}=95)\end{array}$ & $\begin{array}{l}87 \\
(91 \%)\end{array}$ & $\begin{array}{l}8 \\
(8 \%)\end{array}$ \\
\hline $\begin{array}{l}\text { Housewives } \\
(\mathrm{n}=412)\end{array}$ & $\begin{array}{l}345 \\
(83 \%)\end{array}$ & $\begin{array}{l}67 \\
(16 \%)\end{array}$ \\
\hline $\begin{array}{l}\text { Primary and secondary } \\
\text { education } \\
(\mathrm{n}=455)\end{array}$ & $\begin{array}{l}384 \\
(84 \%)\end{array}$ & $\begin{array}{l}71 \\
(15 \%)\end{array}$ \\
\hline $\begin{array}{l}\text { Higher education } \\
(\mathrm{n}=52)\end{array}$ & $\begin{array}{l}48 \\
(92 \%)\end{array}$ & $\begin{array}{l}4 \\
(7 \%)\end{array}$ \\
\hline
\end{tabular}

In all groups, $332(65.50 \%)$ women were affected by their husbands in the choice of contraceptive methods. The women who sought a physician's counselling were only 265 (52.27\%). The women who were knowledgeable about the chosen methods was $48.32 \%(n=245)$. While nulliparous and housewives were significantly affected by their husbands' views in the contraception choice $(\mathrm{p}<0.001)$, education status of women didn't have significant affect $(p=0.987)$. There were no significantly difference in neighbourhoods' views between nulliparous and multiparous women $(\mathrm{p}=0.138)$. But low-educated women and housewives seemed to be significantly affected by neighbourhoods' views $(p<0.001, p=0.017)$.

Table 4. The husband's, neighbourhood's and physician's effects on contraceptive choice and knowledge of the women

\begin{tabular}{|c|c|c|c|c|}
\hline & $\begin{array}{l}\text { Husband's } \\
\text { effect on } \\
\text { choice }\end{array}$ & $\begin{array}{l}\text { Neighbourhood's } \\
\text { effect on choice }\end{array}$ & $\begin{array}{l}\text { Physician's } \\
\text { counselling }\end{array}$ & $\begin{array}{c}\text { Knowledge about } \\
\text { contraceptive } \\
\text { method }\end{array}$ \\
\hline $\begin{array}{l}\text { Age 15-49 } \\
(\mathrm{n}=507)\end{array}$ & $\begin{array}{c}332 \\
(65 \%)\end{array}$ & $\begin{array}{c}181 \\
(35 \%)\end{array}$ & $\begin{array}{c}265 \\
(52 \%)\end{array}$ & $\begin{array}{c}245 \\
(48 \%)\end{array}$ \\
\hline $\begin{array}{l}\text { Nulliparous } \\
(\mathrm{n}=108)\end{array}$ & $\begin{array}{c}86 \\
(79 \%)\end{array}$ & $\begin{array}{c}32 \\
(29 \%)\end{array}$ & $\begin{array}{c}79 \\
(73 \%)\end{array}$ & $\begin{array}{c}45 \\
(41 \%)\end{array}$ \\
\hline $\begin{array}{l}\text { Multiparous } \\
(\mathrm{n}=399)\end{array}$ & $\begin{array}{c}246 \\
(61 \%)\end{array}$ & $\begin{array}{c}149 \\
(37 \%)\end{array}$ & $\begin{array}{c}186 \\
(46 \%)\end{array}$ & $\begin{array}{c}200 \\
(50 \%)\end{array}$ \\
\hline $\begin{array}{l}\text { Employees } \\
(\mathrm{n}=95)\end{array}$ & $\begin{array}{c}78 \\
(82 \%)\end{array}$ & $\begin{array}{c}44 \\
(46 \%)\end{array}$ & $\begin{array}{c}62 \\
(65 \%)\end{array}$ & $\begin{array}{c}54 \\
(56 \%)\end{array}$ \\
\hline $\begin{array}{l}\text { Housewives } \\
(\mathrm{n}=412)\end{array}$ & $\begin{array}{c}254 \\
(61 \%)\end{array}$ & $\begin{array}{c}137 \\
(33 \%)\end{array}$ & $\begin{array}{c}203 \\
(49 \%)\end{array}$ & $\begin{array}{c}191 \\
(46 \%)\end{array}$ \\
\hline $\begin{array}{l}\text { Primary and } \\
\text { secondary } \\
\text { education } \\
(n=455)\end{array}$ & $\begin{array}{c}298 \\
(65 \%)\end{array}$ & $\begin{array}{c}174 \\
(38 \%)\end{array}$ & $\begin{array}{c}222 \\
(48 \%)\end{array}$ & $\begin{array}{c}198 \\
(43 \%)\end{array}$ \\
\hline $\begin{array}{l}\text { Higher } \\
\text { education } \\
(\mathrm{n}=52)\end{array}$ & $\begin{array}{c}34 \\
(65 \%)\end{array}$ & $\begin{array}{c}7 \\
(13 \%)\end{array}$ & $\begin{array}{c}43 \\
(82 \%)\end{array}$ & $\begin{array}{c}47 \\
(90 \%)\end{array}$ \\
\hline
\end{tabular}


Pysician's councelling had significant affect in contraception choice of nulliparous, employed and high-educated women $(\mathrm{p}<0.001, \mathrm{p}=0.005, \mathrm{p}<0.001)$. In all groups, almost half of the women used their contraceptive methods unconsciously; while there were no significant difference about the knowledge of contraceptive methods between nulliparous and multiparous women and employees and housewives, higher educated women were significantly more knowledgeable $(p=0.119, p=0.065, p<0.001)$. The factors affecting the women's contraceptive choices and the knowledge of the women are shown in Table 4.

In the study group, $420(82.81 \%)$ women had left their previous methods for various reasons. Lack of confidence and becoming pregnant were the most frequent reasons given by 188 women $(37 \%)$. The presence of systemic diseases followed it, given by 185 women $(36.56 \%)$. The husbands' effect was $8.37 \%(n=42)$ and physicians' counselling in changing the method was only $0.88 \%(n=2)$. Coitus interruptus was the method most left in all groups $(32.65 \%, n=165)$.

\section{Discussion}

There have been many studies about the contraceptive choices of women and the factors affecting this and the results differed according to the prevailing socioeconomic and sociocultural conditions. In our study, the most used method was the condom which was used by $30.18 \%$ and modern methods seemed to be more preferred. Kara et al. studied women living in Ağrı, which was less developed and where the pregnancy rate were higher in Turkey, and they found IUDs the most used contraceptive method (Kara et al., 2010). Moreover, Aksakal et al. mentioned that the use of modern methods increased from $9 \%$ to $55.2 \%$ in nearby Ankara (Aksakal et al., 2001). However, oral contraceptives were the most used contraceptives in the United States of America among 7356 women in a study by Mosher et al. (2010). Moreover, Skouby (2010) mentioned the same result in a study including five European countries (France, Germany, Italy, Spain and England).

In our study, the effects of husbands' views on the contraceptive choices of women in all groups and the unconscious use of contraception drew our attention. Physicians' counselling was mentioned by $52.27 \%$ of the subjects. The women who had received higher education were more conscious about their methods and had more counselling, however the effect of husbands' and neighbourhs' views didn't differ from other groups. There have been many studies supporting this in the literature. Alpu and Fidan (2006) studied the factors affecting the contraceptive choice of married women and they found that religion was the most effective factor, followed by living region and educational status. They indicated that the use of modern methods increased in those who were higher educated and who lived in urban areas. Furthermore, Topsever at al. (2006) showed that higher educated women had more information about their contraceptive methods and physicians' counselling did not affect this. Moreover Cindoglu et al. (2008) studied the factors involved in choosing coitus interruptus among women and indicated that socioeconomic class, working conditions and educational status affected this choice. Supporting this, in our study group, housewives and less educated women tended to prefer coitus interruptus.

A different approach was taken by Kilıc et al. (2009) about the effect of coitus interruptus among traditional methods on their sexual lives. They showed that the women and their husbands were disturbed by this contraceptive method and they preferred tubal ligation. In our study, $8 \%$ of women indicated the effect of their husbands' views in leaving the previous method and the choice of the new one.

In conclusion, the women were affected by many factors in choosing contraceptive methods. Their husbands had a significant effect in all groups independent of educational status, working conditions and age groups. The neighbourhood seemed to have an effect especially in the less educated women and in housewives. Physicians' counselling is not sufficient and so knowledge about contraception is inadequate. Therefore it must be mentioned that physicians' counselling is important in choosing the most appropriate contraceptive method for the women.

We want to thank to Mrs. Aysel Gonenc who helped us in carrying out of the inquiry.

We declare that we have no conflict of interest.

\section{REFERENCES}

Aksakal, F.N., Ozkan, S., Aycan, S., 2001. The usage of modern contraception methods among 15-49 years age group married women in golbasi education and research health district between 1983-1999. Turk. J. Med. Sci. 21, 445-448.

Alpu, O., Fidan, H., 2006. On the use of contraceptive methods among married women in Turkey. Eur. J. Contracep. Repr. 11, $228-236$.

Cindoglu, D., Sirkeci, I., Sirkeci, R.F., 2008. Determinants of choosing withdrawal over modern contraceptive methods in Turkey. Eur. J. Contracep. Repr. 13, 412-421.

Grewal, M., Burkman Ronald, T., 2003. Contraception Family Planing In: Alan DeCherney, Lauren Nathan (ed) Current Obstetric Gynecology Diagnosis Treatment: 9th edn .U.S.A; Mc Graw Hill Company. 631.

Kara, M., Yilmaz, E., Toz, E., Avci, I., 2010. Agri ilinde kullanilan kontraseptif yontemler. Turkiye Klinikleri J. Gynecol. Obst. 20 , 10-13.

Kilic, A., Akyuz, A., Yavan, T., Guvenc, G., 2009. Kontraseptiflerin cinsel yasantiya etkileri uzerine niteliksel bir calisma. Turkiye klinikleri. J. Gynecol. Obst. 19, 131-141.

Mosher, W.D., Jones, J., 2010. Use of contraception in the United States: 1982-2008.Vital Health. 29 , 1-44.

Skouby, S.O., 2010. Contraceptive use and behavior in the 21 st century: A comprehensive study across five European countries. Eur. J. Contracep. Reprod. Health Care. 15, 42-53.

Stubblefield, P.G., Carr-Ellis, S., Kapp, N., 2007. Family planing. In: Jonathan S Berek (ed) Berek-Novak's Gynecology: 14th edn. U.S.A. Lippincott Williams Wilkins. 247-251.

Topsever, P., Filiz, M., Aladag, M., Topalli, R., Cigerli, O., Gorpelioglu, S., 2006. Councelling and knowledge about contraceptive mode of action among married women: A cross-sectional study. B.M.C. Women Health. 6, 6-12. 